\title{
Althaea rosea Cavanil and Plantago major L. suppress neoplastic cell transformation through the inhibition of epidermal growth factor receptor kinase
}

\author{
EUN-SUN CHOI ${ }^{1 *}$, SUNG-DAE CHO $^{1 *}$, JI-AE SHIN $^{1}$, KI HAN KWON ${ }^{2}$, NAM-PYO CHO ${ }^{1}$ and JUNG-HYUN SHIM ${ }^{3}$ \\ ${ }^{1}$ Department of Oral Pathology, School of Dentistry and Institute of Oral Bioscience, Brain Korea 21 project, \\ Chonbuk National University, Jeonju 561-756; ${ }^{2}$ Department of Food Science and Nutrition, College of Health, \\ Welfare and Education, Gwangju University, Gwangju 503-703; ${ }^{3}$ Department of Biochemistry, \\ College of Medicine, Soonchunhyang University, Cheonan 331-090, Republic of Korea
}

Received February 22, 2012; Accepted June 20, 2012

DOI: $10.3892 / \mathrm{mmr} .2012 .977$

\begin{abstract}
For thousands of years in Asia, Althaea rosea Cavanil (ARC) and Plantago major L. (PML) have been used as powerful non-toxic therapeutic agents that inhibit inflammation. However, the anticancer mechanisms and molecular targets of ARC and PML are poorly understood, particularly in epidermal growth factor (EGF)-induced neoplastic cell transformation. The aim of this study was to evaluate the chemopreventive effects and mechanisms of the methanol extracts from ARC (MARC) and PML (MPML) in EGF-induced neoplastic cell transformation of JB6 P+ mouse epidermal cells using an MTS assay, anchorageindependent cell transformation assay and western blotting. Our results showed that MARC and MPML significantly suppressed neoplastic cell transformation by inhibiting the kinase activity of the EGF receptor (EGFR). The activation of EGFR by EGF was suppressed by MARC and MPML treatment in $\mathrm{EGFR}^{+/+}$cells, but not in $\mathrm{EGFR}^{-/-}$cells. In addition, MARC and MPML inhibited EGF-induced cell proliferation in EGFR-expressing murine embryonic fibroblasts $\left(\mathrm{EGFR}^{+/+}\right)$. These results strongly indicate
\end{abstract}

Correspondence to: Dr Jung-Hyun Shim, Department of Biochemistry, College of Medicine, Soonchunhyang University, Ssangyong-dong, Seobuk-gu, Cheonan, Choongnam 331-090, Republic of Korea

E-mail: s1004jh@gmail.com

*Contributed equally

Abbreviations: ARC, Althaea rosea Cavanil; PML, Plantago major L.; EGF, epidermal growth factor; MARC, methanol extracts Althaea rosea Cavanil; MPML, methanol extracts Plantago major L.; EGFR, epidermal growth factor receptor; MEM, minimal essential medium; DMEM, Dulbecco's modified essential medium; MEFs, mouse embryonic fibroblasts; FBS, fetal bovine serum; MTS, (3-(4,5-dimethylthiazol-20yl)-(3-carboxymethoxyphenyl)-2-(4sulphophenyl)-2H-tetrazolium); BME, basal medium Eagle

Key words: Althaea rosea Cavanil, Plantago major L., skin carcinogenesis, epidermal growth factor receptor that EGFR targeting by MARC and MPML may be a good strategy for chemopreventive or chemotherapeutic applications.

\section{Introduction}

Epidermal growth factor receptor (EGFR) is a $175-\mathrm{kDa}$ trans-membrane glycoprotein in the tyrosine kinase family of growth factor receptors (1). EGFR has been reported to be overexpressed in various types of cancer, including lung, colon and head and neck cancer. Additionally, the activation of the EGFR cascades may result in various cell responses including apoptosis, development, cell proliferation, differentiation and survival (2-7). The overexpression and activation of EGFR is a common mechanism by which EGFR exerts its influence on tumorigenesis $(1,8-11)$. Thus, EGFR is a potential target for cancer therapy due to its expression and activity in cancer tissues.

Natural products from medicinal plants have been used for a long time due to their potential chemotherapeutic activity $(12,13)$. A recent review by Graham et al reported the use of Plantago major L. (PML) as an antitumor agent (13-15). Another plant that is used as a medicinal agent for the treatment of dry cough, catarrhal inflammation of the throat and oesophagus, as well as irregular or absent menstrual cycles is Althaea rosea cavanil (ARC) (16). However, the mechanisms of PML and ARC involved in the suppression of various tumors are unknown, although PML and ARC have been used as traditional medicines to treat several diseases.

In this study, methanolic extracts from Plantago major L. (MPML) and Althaea rosea Cavanil (MARC) were studied for their anti-tumorigenic effects via the inhibition of transformed normal cells. Consequently, the present study aimed to identify the molecular mechanisms and direct targets of the anti-tumorigenic effects of MARC and MPML in tumor promoter (EGF)-induced neoplastic cell transformation.

\section{Materials and methods}

Reagents. Eagle's minimal essential medium (MEM) and Dulbecco's modified essential medium (DMEM) were 
obtained from Welgene, Inc. (Korea). EGF was purchased from Invitrogen (Carlsbad, CA, USA). Antibodies to pEGFR and EGFR were obtained from Cell Signaling, Inc. (Danvers, MA, USA). Anti-actin antibody was obtained from Santa Cruz Biotechnology, Inc. (Santa Cruz, CA, USA). MARC and MPML were kindly supplied by Professor Ki Han Kwon (Gwangju University, Gwangju, Korea).

Cell culture and chemical treatments. $\mathrm{EGFR}^{+/+}$and $\mathrm{EGFR}^{-1}$ mouse embryonic fibroblasts (MEFs) were kindly provided by Professor Dong (University of Minnesota, Hormel Institute, MN, USA) (11) and the JB6 P+ (JB6 CI 41-5a) mouse epidermal cell line was obtained from the American Tissue Culture Collection (Manassas, VA, USA). The JB6 P+ cells were cultured in MEM containing 5\% fetal bovine serum (FBS) and MEF cells were maintained in DMEM containing $10 \%$ FBS, each with $100 \mathrm{U} / \mathrm{ml}$ of penicillin (Welgene, Inc.), in a humidified atmosphere containing $5 \% \mathrm{CO}_{2}$. An equal number of cells were seeded and allowed to attach overnight. The cells were starved in $0.1 \%$ FBS/MEM or DMEM for $24 \mathrm{~h}$, incubated with MARC (30,60 and $90 \mu \mathrm{g} / \mathrm{ml})$ or MPML (20, 40 and $60 \mu \mathrm{g} / \mathrm{ml}$ ) for $1 \mathrm{~h}$ and treated with $10 \mathrm{ng} / \mathrm{ml}$ of EGF.

MTS assay. The effects of MARC and MPML on cell viability were estimated using the CellTiter $96^{\circledR}$ Aqueous One Solution Cell Proliferation Assay (Promega, Madison, WI, USA) according to the manufacturer's instructions. In brief, cells were seeded in 96-well plates and then incubated with various doses of MARC $(30,60,90$ and $120 \mu \mathrm{g} / \mathrm{ml})$ and MPML (20, $40,60$ and $80 \mu \mathrm{g} / \mathrm{ml})$ for $72 \mathrm{~h}$. MTS (3-(4,5-dimethylthiazol-20yl)-(3-carboxymethoxyphenyl)-2-(4-sulphophenyl)-2Htetrazolium) solution was added to each well and incubated for $2 \mathrm{~h}$ at $37^{\circ} \mathrm{C}$. The reaction buffer was analyzed using an ELISA microplate reader (BioTeck Instruments Inc., Winooski, VT, USA) at 490 and $690 \mathrm{~nm}$ (background).

Anchorage-independent cell transformation assay. The effect of MARC and MPML on EGF-induced cell transformation was estimated in JB6 P+ cells. The cells were treated with EGF (10 $\mathrm{ng} / \mathrm{ml})$ with or without various doses of MARC and MPML in $1 \mathrm{ml}$ of $0.33 \%$ basal medium Eagle's (BME) agar over $3 \mathrm{ml}$ of $0.5 \% \mathrm{BME}$ agar containing $10 \% \mathrm{FBS}$. The cultures were maintained at $37^{\circ} \mathrm{C}$ in a $5 \% \mathrm{CO}_{2}$ incubator for 10 days and the cell colonies were counted using a microscope.

Western blot analysis. Whole cell lysates were collected in lysis buffer for the western blot analysis. The protein supernatant fractions were subjected to SDS-PAGE and then transferred on polyvinylidene difluoride membranes and blocked with 5\% skimmed milk followed by hybridization with the indicated antibodies. The protein bands with horseradish peroxidase-conjugated secondary antibody were observed using a western blotting luminol reagent (Santa Cruz Biotechnology, Inc.).

Statistical analysis. Data were assessed as the means \pm SD. of triplicate samples from at least three independent experiments. Statistical significance was evaluated using a Student's t-test or one-way ANOVA and was considered significant when $\mathrm{p}<0.05$.
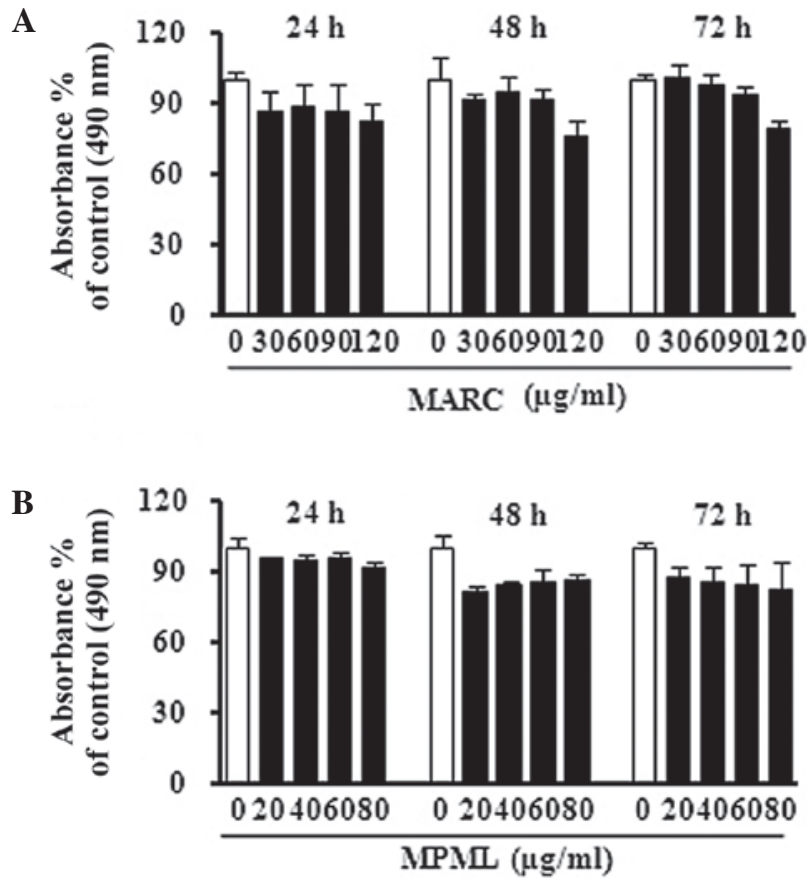

Figure 1. Effect of (A) MARC and (B) MPML on cell viability of JB6 P+ cells. JB6 P+ cells $\left(1 \times 10^{3}\right.$ cells $\left./ 100 \mu 1\right)$ were seeded in 96 -well plates and incubated for $72 \mathrm{~h}$ with increasing concentrations of MARC and MPML. Cell viability was estimated using a CellTiter 96 non-radioactive cell proliferation assay, as described in Materials and methods. The graph indicates the average of triplicate samples from three independent experiments. MARC, methanol extracts of Althaea rosea Cavanil; MPML, methanol extracts of Plantago major L.

\section{Results}

MARC and MPML do not affect cell proliferation in JB6 P+ cells. To determine whether MARC and MPML had cell growth inhibitory effects, we treated JB6 P+ epidermal mouse skin cells with MARC and MPML at a range of doses and assessed viability using the MTS assay. The results showed that MARC and MPML did not significantly affect cell proliferation at 24,48 or $72 \mathrm{~h}$ after treatment (Fig. 1).

MARC and MPML markedly suppress EGF-induced neoplastic transformation in JB6 P+ cells. The JB6 P+ cell line is an excellent model to study EGF-induced cell transformation (17). We evaluated whether MARC and MPML is directly associated with EGF-induced neoplastic transformation. The results showed that MARC and MPML significantly decreased the EGF-promoted colony number and colony size in a dosedependent manner. Colony formation and colony size induced by EGF-induced JB6 P+ cells was also significantly less than that observed in the non-treated JB6 P+ cells (Fig. 2A and B).

MARC and MPML inhibit EGF-induced EGFR phosphorylation in JB6 P+cells. Numerous studies have shown that EGF promoted skin carcinogenesis through EGFR activation $(6,7)$. To verify whether phosphorylation of EGFR was induced by EGF, we tested the expression of EGFR phosphorylation with EGF for increasing time periods. The results showed that the expression of EGFR phosphorylation significantly increased within 5-20 min after treatment with EGF (Fig. 3A). We tested whether MARC and MPML downregulated the phosphorylation 
A

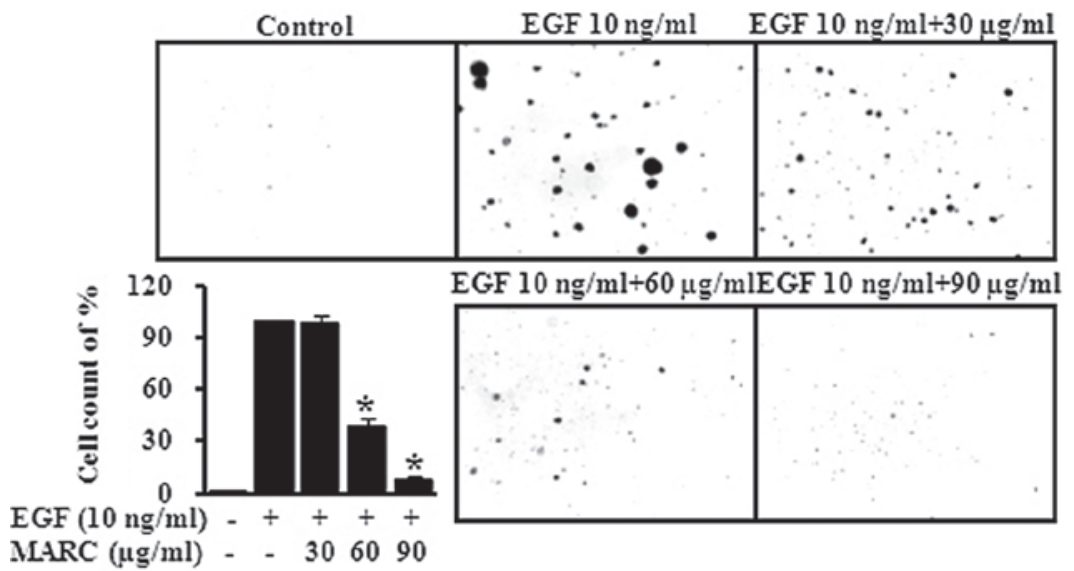

B

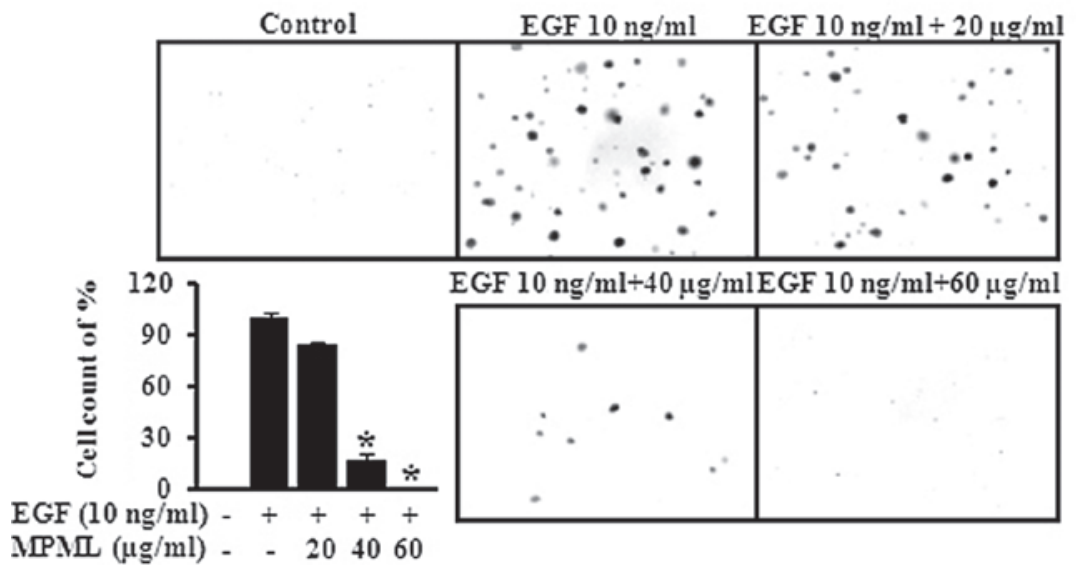

Figure 2. Effect of (A) MARC and (B) MPML on EGF-induced neoplastic cell transformation in JB6 P+ cells. JB6 P+ cells were treated with or without MARC and MPML, and exposed to EGF $(10 \mathrm{ng} / \mathrm{ml})$ in $1 \mathrm{ml}$ of $0.3 \%$ basal medium Eagle's agar containing $10 \% \mathrm{FBS}$. The culture was maintained at $37^{\circ} \mathrm{C}$ in a $5 \% \mathrm{CO}_{2}$ atmosphere for 10 days, after which colonies were counted automatically. MARC, methanol extracts of Althaea rosea Cavanil; MPML, methanol extracts of Plantago major L.; EGF, epidermal growth factor; FBS, fetal bovine serum. The asterisk indicates a significant difference $(\mathrm{P}<0.05)$ between groups treated with EGF and MARC or MPML, and the group treated with EGF alone.

of EGFR activated by EGF in JB6 P+ cells. Our results indicated that MARC $(90 \mu \mathrm{g} / \mathrm{ml})$ and MPML $(60 \mu \mathrm{g} / \mathrm{ml})$ suppressed the EGF-induced phosphorylation of EGFR (Fig. 3B and C). These results suggested that the inactivation of EGFR by MARC and MPML leads to the suppression of neoplastic transformation.

MARC and MPML inhibit the EGF-induced phosphorylation of EGFR and suppress the EGF-induced cell proliferation in an MEF cell line. MARC and MPML strongly inhibited the EGF-induced phosphorylation of EGFR in JB6 P+ cells (Fig. 3). Thus, we investigated the direct effect of MARC and MPML on the phosphorylation of EGFR in EGF knockout MEF cells $\left(\mathrm{EGFR}^{-/}\right)$and EGFR-expressing MEF cells $\left(\mathrm{EGFR}^{+/+}\right)$. MARC and MPML decreased the EGF-induced phosphorylation of EGFR in EGFR/WT MEF cells, but not in EGFR KO MEF cells (Fig. 4A and B). To further explore the inhibitory effect of MARC and MPML on EGF-induced cell proliferation, EGFR ${ }^{+/+}$ cells were cultured for $24 \mathrm{~h}$ in 96 -well culture plates with MARC $(90 \mu \mathrm{g} / \mathrm{ml})$ and MPML $(60 \mu \mathrm{g} / \mathrm{ml})$ and cell proliferation was measured using the MTS assay. Treatment with EGF $(10 \mathrm{ng} / \mathrm{ml})$ resulted in an $\sim 60 \%$ increase compared to the DMSO control in the $\mathrm{EGFR}^{+/+}$cells, but MARC $(90 \mu \mathrm{g} / \mathrm{ml})$ and MPML $(60 \mu \mathrm{g} /$ $\mathrm{ml}$ ) inhibited EGF-induced cell proliferation in $\mathrm{EGFR}^{+/+}$cells. These results indicated that $\mathrm{EGFR}^{+/+} \mathrm{MEF}$ proliferation affects the inhibition of EGFR activation by MARC and MPML.

\section{Discussion}

Cancer is a major public health problem. Numerous studies have indicated that chemotherapeutic drugs cannot successfully treat cancer as they have severe side effects including various types of rash, hair loss, painful paronychia and xerosis cutis (18). Plants as medicinal agents have been used in the treatment of various types of diseases in humans (19-23) and a number of investigators have also reported that natural products may be safe and free from side effects (24-27). Particularly, PML as a natural product, has been reported to exert its anticancer effect via DNA damage in cancer cells (15). Wang et al also reported that ARC inhibited inflammation in rat paw edema (28). However, no study currently exists on the anti-cancer activity and related molecular targets of ARC and PML.

In this study, we focused on three primary objectives in relation to the chemopreventive effect of ARC and PML in EGF-induced neoplastic cell transformation. The first was to examine the effect of ARC and PML on the cell toxicity of mouse epidermal JB6 P+ cells. The second was to determine the anti-tumorigenic effect of ARC and PML on EGF-induced neoplastic cell transformation. The third was to identify critical key molecules in mouse skin anti-cancer activities by ARC and PML. For this study, ARC and PML were extracted with methanol. We investigated whether MARC and MPML were 
A

EGF $(10 \mathrm{ng} / \mathrm{ml})$

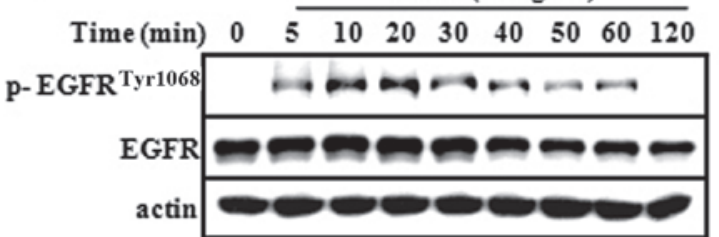

B

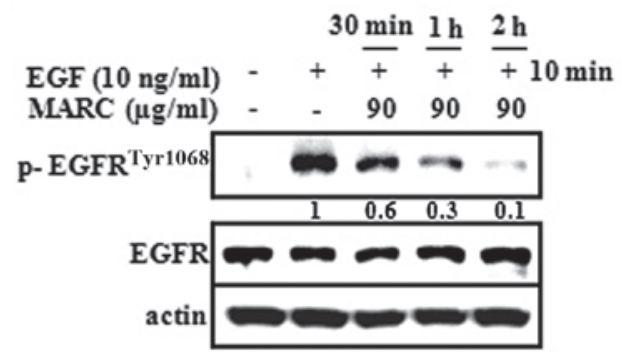

C

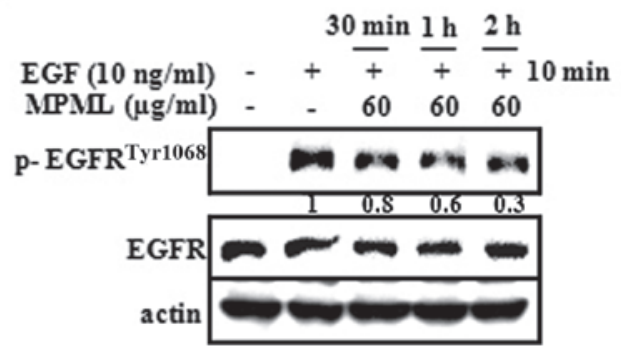

Figure 3. Inhibitory effect of MARC and MPML on EGF-induced EGFR phosphorylation. JB6 $\mathrm{P}+$ cells were starved for $24 \mathrm{~h}$ via incubation in serumdeprived MEM at $37^{\circ} \mathrm{C}$ in a $5 \% \mathrm{CO}_{2}$ atmosphere, treated with MARC and MPML for $30 \mathrm{~min}, 1$ and $2 \mathrm{~h}$ and then exposed to EGF $(10 \mathrm{ng} / \mathrm{ml})$ for $10 \mathrm{~min}$. Whole cell lysates were collected for the western blotting with antibodies detecting phosphorylated EGFR as described in Materials and methods (A) Time-course expression of EGFR phosphorylation was detected by EGF-stimulation. (B and C) MARC and MPML inhibit EGFR phosphorylation induced by EGF. MARC, methanol extracts of Althaea rosea Cavanil; MPML, methanol extracts of Plantago major L.; EGF, epidermal growth factor; EGFR, epidermal growth factor receptor.

cytotoxic in the mouse epidermal JB6 P+ cells. The results showed that MARC and MPML did not have any effect on the viability of JB6 P+ cells when treated at various doses.

The irregular biological process of tumorigenesis is associated with the abnormal regulation of growth signaling. EGF is one of the tumor promoters that is capable of causing the induction of abnormal cell growth (29) and the EGF-EGFR transduction system has been confirmed to be significantly increased in human cancer cells of the skin, breast, colon, lung and prostate to stimulate cell proliferation, invasiveness and angiogenesis $(11,30,31)$. The JB6 P+ cell line is a well-established system extensively used as an in vitro model for the study of tumor promotion $(32,33)$ and provides an ideal model for the investigation of the molecular mechanisms involved in neoplastic transformation, promotion and progression (11,34-36). Notably, it has been reported that EGF induced the formation of anchorage-independent colonies in JB6 P+ cells using a soft agar assay $(11,33,37)$. Therefore, we investigated whether MARC and MPML are capable of suppressing the EGF-induced neoplastic cell transformation. We showed that MARC and MPML clearly inhibited EGF-induced neoplastic cell transformation as well as colony number and
A

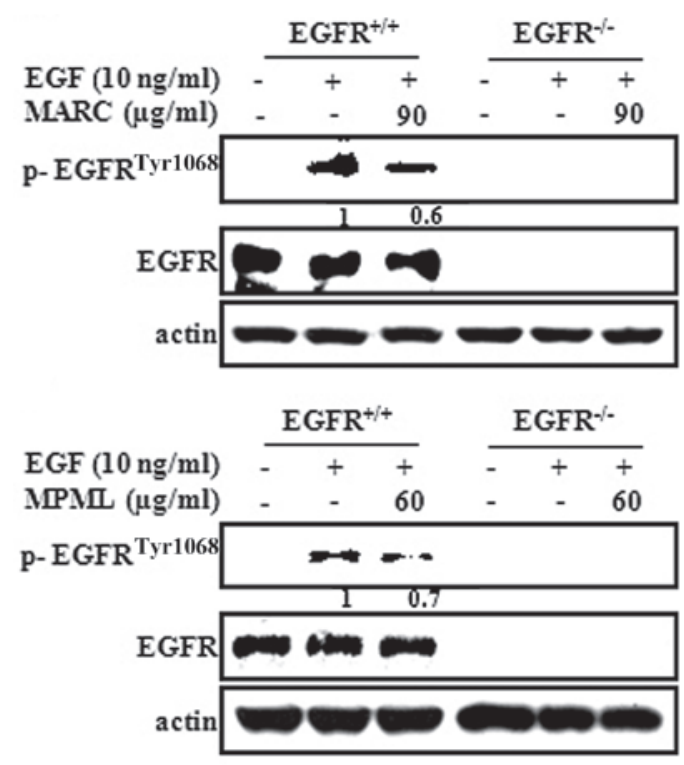

C

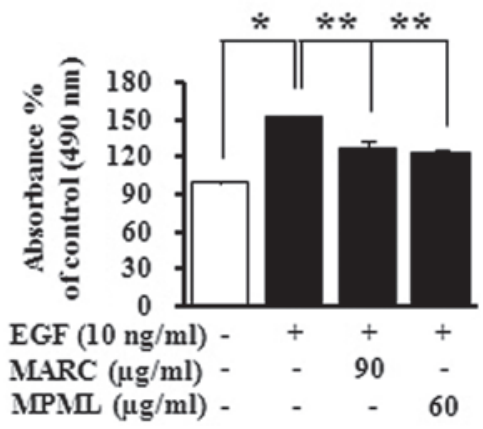

Figure 4. MARC and MPML inhibited EGF-induced proliferation and EGFR phosphorylation in EGFR wild-type (WT) (+/+) and knockout (-/-) MEFs. (A and B) Treatment with MARC and MPML inhibited EGFR phosphorylation only in EGFR/WT MEFs. After EGFR/WT and KO MEFs were starved for $24 \mathrm{~h}$ via incubation in serum-deprived MEM at $37^{\circ} \mathrm{C}$ in a $5 \% \mathrm{CO}_{2}$ atmosphere, cells were treated with MARC $90 \mu \mathrm{g} / \mathrm{ml}$ and MPML $60 \mu \mathrm{g} / \mathrm{ml}$ for $1 \mathrm{~h}$, followed by EGF $(10 \mathrm{ng} / \mathrm{ml})$ for $10 \mathrm{~min}$. Cells were lysed and EGFR phosphorylation expression was analyzed by western blotting. (C) MARC and MPML significantly decreased EGF-induced cell proliferation only in EGFR/WT MEFs. Cell proliferation was estimated using the CellTiter 96 non-radioactive cell proliferation assay at an absorbance of $490 \mathrm{~nm}$. The graph is representative for three independent experiments and bars show the mean $\pm \mathrm{SD} .{ }^{*} \mathrm{P}<0.05$ versus control group. ${ }^{* *} \mathrm{P}<0.05$ versus EGF-treated group. MARC, methanol extracts of Althaea rosea Cavanil; MPML, methanol extracts of Plantago major L.; EGF, epidermal growth factor; EGFR, epidermal growth factor receptor; MEFs, mouse embryonic fibroblasts.

size in EGF-treated JB6 P+ cells, indicating that MARC and MPML could be acting as anti-cancer agents. EGFR has been recognized as a convergence point for diverse signal transduction pathways (37-39). After EGF binds with the ectodomain of the EGFR, which exists as homodimers or heterodimers, this leads to the autophosphorylation of tyrosine residues in the cytoplasmic domain and activation of the receptor's intrinsic kinase activity $(11,40)$. Notably, EGFR is frequently overexpressed and abnormally activated in many types of cancer. Thus, we examined whether MARC and MPML inhibited EGF-induced EGFR phosphorylation to suppress neoplastic cell transformation in EGFR-expressing cells (JB6 P+, EGFR $\left.{ }^{+/}\right)$. These results suggested that MARC and MPML significantly inhibited the phosphorylation of EGFR by EGF on JB6 P+ and EGFR ${ }^{+/+}$ cells, but not $\mathrm{EGFR}^{-/}$cells. MARC and MPML effectively 
inhibited the EGF-induced proliferation of $\mathrm{EGFR}^{+/+}$cell lines. Our data suggest that the dephosphorylation of EGFR may be associated with MARC- and MPML-suppressed neoplastic cell transformation and cell proliferation in JB6 P+ cells.

In conclusion, MARC and MPML have suppressed EGF-induced transformation and proliferation through the dephosphorylation of EGFR. Thus, MARC and MPML are capable of inhibiting the growth of cancer cells through EGFR and may be developed into effective anticancer agents against various types of cancer that highly express EGFR.

\section{Acknowledgements}

This study was supported by the Basic Science Research program through the National Research Foundation Korea (NRF) funded by the Ministry of Education, Science and Technology (2012-0003226), and the Next-Generation BioGreen 21 Program (PJ008116062011), Rural Development Administration, Republic of Korea.

\section{References}

1. Wang H, Zhou M, Shi B, et al: Identification of an exon 4-deletion variant of epidermal growth factor receptor with increased metastasis-promoting capacity. Neoplasia 13: 461-471, 2011.

2. Xue C, Wyckoff J, Liang F, et al: Epidermal growth factor receptor overexpression results in increased tumor cell motility in vivo coordinately with enhanced intravasation and metastasis. Cancer Res 66: 192-197, 2006.

3. Pandiella A, Lehvaslaiho H, Magni M, Alitalo K and Meldolesi J: Activation of an EGFR/neu chimeric receptor: early intracellular signals and cell proliferation responses. Oncogene 4: 1299-1305, 1989.

4. Liang K, Ang KK, Milas L, Hunter N and Fan Z: The epidermal growth factor receptor mediates radioresistance. Int J Radiat Oncol Biol Phys 57: 246-254, 2003.

5. Ho R, Minturn JE, Hishiki T, et al: Proliferation of human neuroblastomas mediated by the epidermal growth factor receptor. Cancer Res 65: 9868-9875, 2005.

6. Modjtahedi H and Essapen S: Epidermal growth factor receptor inhibitors in cancer treatment: advances, challenges and opportunities. Anticancer Drugs 20: 851-855, 2009.

7. Engelman JA and Cantley LC: A sweet new role for EGFR in cancer. Cancer Cell 13: 375-376, 2008.

8. Chaffanet M, Chauvin C, Laine M, et al: EGF receptor amplification and expression in human brain tumours. Eur J Cancer 28 : 11-17, 1992.

9. Nishikawa R, Ji XD, Harmon RC, et al: A mutant epidermal growth factor receptor common in human glioma confers enhanced tumorigenicity. Proc Natl Acad Sci USA 91: 7727-7731, 1994.

10. Tang P, Steck PA and Yung WK: The autocrine loop of TGF-alpha/ EGFR and brain tumors. J Neurooncol 35: 303-314, 1997.

11. Hwang MK, Bode AM, Byun S, et al: Cocarcinogenic effect of capsaicin involves activation of EGFR signaling but not TRPV1. Cancer Res 70: 6859-6869, 2010.

12. Newman DJ, Cragg GM and Snader KM: Natural products as sources of new drugs over the period 1981-2002. J Nat Prod 66: $1022-1037,2003$

13. Graham JG, Quinn ML, Fabricant DS and Farnsworth NR: Plants used against cancer - an extension of the work of Jonathan Hartwell. J Ethnopharmacol 73: 347-377, 2000.

14. Samuelsen AB: The traditional uses, chemical constituents and biological activities of Plantago major L. A review. J Ethnopharmacol 71: 1-21, 2000.

15. Galvez M, Martin-Cordero C, Lopez-Lazaro M, Cortes F and Ayuso MJ: Cytotoxic effect of Plantago spp. on cancer cell lines. J Ethnopharmacol 88: 125-130, 2003.

16. Papiez MA: The influence of hollyhock extract administration on testicular function in rats. J Mol Histol 35: 733-740, 2004.

17. Kang NJ, Lee KW, Rogozin EA, et al: Equol, a metabolite of the soybean isoflavone daidzein, inhibits neoplastic cell transformation by targeting the MEK/ERK/p90RSK/activator protein-1 pathway. J Biol Chem 282: 32856-32866, 2007.
18. Ehmann LM, Heinemann V and Wollenberg A: New tyrosine kinase and EGFR inhibitors in cancer therapy : Cardiac and skin toxicity as relevant side effects. Part B: skin. Internist (Berl) 52: 1359-1364, 2011 (In German).

19. Cheung CW, Gibbons N, Johnson DW and Nicol DL: Silibinin - a promising new treatment for cancer. Anticancer Agents Med Chem 10: 186-195, 2010.

20. Fahey JW, Haristoy X, Dolan PM, et al: Sulforaphane inhibits extracellular, intracellular, and antibiotic-resistant strains of Helicobacter pylori and prevents benzo[a]pyrene-induced stomach tumors. Proc Natl Acad Sci USA 99: 7610-7615, 2002.

21. Yanaka A, Fahey JW, Fukumoto A, et al: Dietary sulforaphanerich broccoli sprouts reduce colonization and attenuate gastritis in Helicobacter pylori-infected mice and humans. Cancer Prev Res (Phila) 2: 353-360, 2009.

22. Butler MS: The role of natural product chemistry in drug discovery. J Nat Prod 67: 2141-2153, 2004.

23. Koehn FE and Carter GT: The evolving role of natural products in drug discovery. Nat Rev Drug Discov 4: 206-220, 2005.

24. Shokrzadeh M, Azadbakht M, Ahangar N, Hashemi A and Saeedi Saravi SS: Cytotoxicity of hydro-alcoholic extracts of Cucurbitapepo and Solanum nigrum on HepG2 and CT26 cancer cell lines. Pharmacogn Mag 6: 176-179, 2010.

25. Etkin NL: A Hausa herbal pharmacopoeia: biomedical evaluation of commonly used plant medicines. J Ethnopharmacol 4: 75-98, 1981.

26. Misumi N, Hiraike M, Nawata F, et al: [Protective effects of d-chlorpheniramine maleate pre-treatment against acute side effects of Irinotecan(CPT- 11)]. Gan To Kagaku Ryoho 38: 1149-1153, 2011 (In Japanese).

27. Sun X, Zhang J, Gupta R, Macgibbon AK, Kuhn-Sherlock B and Krissansen GW: Dairy milk fat augments paclitaxel therapy to suppress tumour metastasis in mice, and protects against the sideeffects of chemotherapy. Clin Exp Metastasis 28: 675-688 2011.

28. Wang DF, Shang JY and Yu QH: Analgesic and anti-inflammatory effects of the flower of Althaea rosea (L.) Cav. Zhongguo Zhong Yao Za Zhi 14: 46-48, 64, 1989 (In Chinese).

29. Furuse J: Growth factors as therapeutic targets in HCC. Crit Rev Oncol Hematol 67: 8-15, 2008

30. Khalil MY, Grandis JR and Shin DM: Targeting epidermal growth factor receptor: novel therapeutics in the management of cancer. Expert Rev Anticancer Ther 3: 367-380, 2003.

31. Mimeault M, Pommery N and Henichart JP: New advances on prostate carcinogenesis and therapies: involvement of EGF-EGFR transduction system. Growth Factors 21: 1-14, 2003.

32. Amstad PA, Liu H, Ichimiya M, Berezesky IK and Trump BF: Manganese superoxide dismutase expression inhibits soft agar growth in JB6 clone41 mouse epidermal cells. Carcinogenesis 18: 479-484, 1997.

33. Kang NJ, Lee KW, Kwon JY, et al: Delphinidin attenuates neoplastic transformation in JB6 C141 mouse epidermal cells by blocking Raf/mitogen-activated protein kinase kinase/ extracellular signal-regulated kinase signaling. Cancer Prev Res (Phila) 1: 522-531, 2008

34. Dong Z and Bode AM: Proceedings - targeting carcinogenesis: transduction, transcription, translation. Mol Carcinog 45: 353-354, 2006.

35. Nguyen-Ba G and Vasseur P: Epigenetic events during the process of cell transformation induced by carcinogens (Review). Oncol Rep 6: 925-932, 1999.

36. Lee KW, Kang NJ, Rogozin EA, et al: Myricetin is a novel natural inhibitor of neoplastic cell transformation and MEK1. Carcinogenesis 28: 1918-1927, 2007.

37. Ciardiello F and Tortora G: EGFR antagonists in cancer treatment. N Engl J Med 358: 1160-1174, 2008.

38. Gschwind A, Zwick E, Prenzel N, Leserer M and Ullrich A: Cell communication networks: epidermal growth factor receptor transactivation as the paradigm for interreceptor signal transmission. Oncogene 20: 1594-1600, 2001.

39. Fichera A, Little N, Jagadeeswaran S, et al: Epidermal growth factor receptor signaling is required for microadenoma formation in the mouse azoxymethane model of colonic carcinogenesis. Cancer Res 67: 827-835, 2007.

40. Wakeling AE, Guy SP, Woodburn JR, et al: ZD1839 (Iressa): an orally active inhibitor of epidermal growth factor signaling with potential for cancer therapy. Cancer Res 62: 5749-5754, 2002. 